\title{
"Post-crisis trends in household credit market behavior: evidence from Hungary (Literature review)"
}

\begin{tabular}{|c|c|}
\hline AUTHORS & $\begin{array}{l}\text { Judit Sági (D https://orcid.org/0000-0003-4197-3530 } \\
\text { R http://www.researcherid.com/rid/AAL-9052-2020 } \\
\text { Csaba Lentner (D https://orcid.org/0000-0003-2241-782X } \\
\text { R http://www.researcherid.com/rid/J-2382-2016 }\end{array}$ \\
\hline ARTICLE INFO & $\begin{array}{l}\text { Judit Sági and Csaba Lentner (2019). Post-crisis trends in household credit } \\
\text { market behavior: evidence from Hungary (Literature review). Banks and Bank } \\
\text { Systems, } 14(3), 162-174 \text {. doi:10.21511/bbs.14(3).2019.14 }\end{array}$ \\
\hline DOI & http://dx.doi.org/10.21511/bbs.14(3).2019.14 \\
\hline RELEASED ON & Monday, 07 October 2019 \\
\hline RECEIVED ON & Thursday, 01 August 2019 \\
\hline ACCEPTED ON & Wednesday, 18 September 2019 \\
\hline LICENSE & $\begin{array}{l}(c)) E Y \\
\text { This work is licensed under a Creative Commons Attribution } 4.0 \text { International } \\
\text { License }\end{array}$ \\
\hline JOURNAL & "Banks and Bank Systems" \\
\hline ISSN PRINT & $1816-7403$ \\
\hline ISSN ONLINE & $1991-7074$ \\
\hline PUBLISHER & LLC "Consulting Publishing Company "Business Perspectives" \\
\hline FOUNDER & LLC "Consulting Publishing Company "Business Perspectives" \\
\hline
\end{tabular}

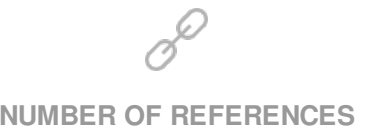

55

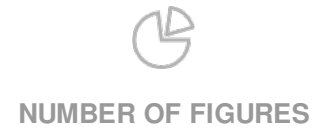

3
NUMBER OF TABLES

2

(C) The author(s) 2023. This publication is an open access article. 


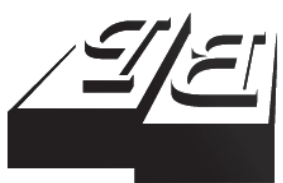

BUSINESS PERSPECTIVES

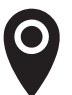

LLC "CPC "Business Perspectives" Hryhorii Skovoroda lane, 10, Sumy, 40022, Ukraine

www.businessperspectives.org

Received on: $1^{\text {st }}$ of August, 2019 Accepted on: $18^{\text {th }}$ of September, 2019

(C) Judit Sági, Csaba Lentner, 2019

Judit Sági, Associate Professor, Faculty of Finance and Accounting, Department of Finance, Budapest Business School, Hungary.

Csaba Lentner, corespondent author, Full Professor, Faculty of Science of Public Governance and Administration, Public Finance Research Institute, National University of Public Service, Hungary.

\section{(ㄷ)(i)}

This is an Open Access article, distributed under the terms of the Creative Commons Attribution 4.0 International license, which permits unrestricted re-use, distribution, and reproduction in any medium, provided the original work is properly cited.
Judit Sági (Hungary), Csaba Lentner (Hungary)

POST-CRISIS TRENDS

IN HOUSEHOLD CREDIT MARKET

BEHAVIOR: EVIDENCE FROM HUNGARY (LITERATURE REVIEW)

\begin{abstract}
In response to a sharp rise in household credit repayment risk after the 2008 crisis, the banking sector was consolidated, borrowing conditions were tightened and the regulatory authorities had to improve the financial literacy of population. The study evaluates the effectiveness of regulatory measures to prevent excessive indebtedness, and analyzes the results of the latest survey of population financial literacy in Hungary after the 2008 financial crisis. The results confirm the scientific studies of different economists and scholars who state that the financial awareness is closely related to household saving and borrowing patterns. The outcomes of the analysis reveal the risks associated with the lack of financial literacy in Hungary. In fact, the financial awareness of households over the past years has not improved significantly either in the wake of losses suffered on FX-based loans, or as a result of the preventive actions undertaken by the government regulatory bodies.
\end{abstract}

\section{Keywords financial awareness, financial literacy, household budgeting, Hungary}

\section{JEL Classification D14, D91, I25}

\section{INTRODUCTION}

One of the biggest challenges facing the modern economy was 2008, when much of the world felt the effects of the financial crisis. It has affected almost everyone: states, banks, financial corporations, etc. Besides, ordinary citizens and their households experienced its effects. This crisis did not walk past Hungary as well. Although ten years have passed since then, its echo is still felt.

Based on the cyclicality theory, many experts predict a recurrence of the 2008 financial disaster in the near term. Therefore, the study of this phenomenon is important, including in terms of governments' actions on households and the response to these actions.

\section{LITERATURE REVIEW}

The 2008 crisis shed light on the fact that micro-prudential interventions focusing on discrete banking problems and risks were insufficient alone to prevent systemic financial disturbances (Akinci \& Olmstead, 2015; Boar et al., 2017). In the period that followed the crisis, one of the characteristic government responses to excessive indebtedness was the establishment of macro-prudential competences and toolboxes: interest and FX fixing operations were meant to adjust household financial charges to their loan repayment ability (Carreras 
et al., 2016; Cerrutti et al., 2017). Of all the debt cap rules, most countries started to apply the loanto-value ratio, which shows the ratio of a loan to its underlying collateral, and indicators that measure debtors' repayment ability. In the latter group, two types of indicators were characteristically adopted:

1) payment-to-income (PTI) ratios, which limit the monthly repayment amount relative to the debtor's income; and

2) loan-to-income (LTI) indicators, which determine the maximum amount of loan allowed to be granted based on the debtor's annual income.

The 2018 data suggest that aside from Hungary, Slovakia was the only other Central and Eastern European country that enacted mandatory loanto-value indicators and income-proportionate limits to repayment instalments, while the other countries of the region (the Czech Republic, Poland, Slovenia and Croatia) worded recommendations or codified mandatory regulations only about the loan-to-value ratio, while setting a limit to repayment instalments relative to income in the form of recommendations (Romania; for more details see Dancsik et al.).

However, the individual countries identifiably differ in the regulatory enactments they apply (Seregdi et al., 2015; Fáykiss et al., 2018). In Hungary, the relevant regulations have a broad institutional scope, as in addition to credit institutions, they also apply to non-bank lenders, and this reduces the opportunity to circumvent the regulations. In addition to Hungary, only Estonia and Slovakia have regulations that codify the necessity of prudent evidence for incomes after taxes, the other countries that apply mandatory regulations leave it to banks to determine the scope of eligible incomes. Differentiation according to risk dimensions is characteristic of several countries, with special focus on denomination, and thus FX loans are subject to more stringent limitations (see Hungary and Romania). Exceptions to the debt cap rules are applied in several states for less risky groups of borrowers. The Czech Republic, Slovakia, Estonia and Lithuania provide the opportunity for the disbursement of loans with LTV or PIT values above the requirement.
According to the National Bank of Hungary (2017, 2018), since mid-2016, debt cap rules have become increasingly widespread or stricter in Europe. The Northern European and the Central and Eastern European Member States of the European Union still take the lead in the application of such regulations, which - in the case of the latter countries

- are not independent of the higher financial vulnerability of households. Notwithstanding the above, central banks regularly measure the population's financial literacy and sensitiveness to the deterioration of financial conditions.

In Hungary, the prolonged crisis was accompanied by deterioration in the FX-based household mortgage loan portfolio. In response, in addition to credit institutions' debtor rescue plans, the regulatory authority elaborated several debtor rescue packages (including the conversion of foreign currency loans to forint loans or exchange rate fixing, see Kovács (2013). This analysis points out that although macro-prudential rules, decrease in FX-settled lending and the expansion of fixed-rate loans have effectively reduced household vulnerability, special attention should be paid to the findings of research in financial culture, as it has been revealed that borrower consciousness remains poor.

This paper is structured as follows. Section 1 describes the procedure of households' repeated indebtedness placed in an international setting, and especially through the example of Hungary. This is followed by the concept of financial literacy in the context of the international literature, making reference to the OECD methodology elaborated for measuring financial literacy. Further, the outcomes of the 2018 survey of households, performed according to the OECD methodology are described. They are analyzed in a macro-prudential perspective. Finally, in conclusion, recommendations are made in relation to households' financial vulnerability and the repeated accumulation of loans.

\subsection{Repeated household indebtedness in an international context and Hungary}

Households' financial vulnerability correlates with the level of their indebtedness. Based on the OECD (2017) data, household indebtedness indicators rose in nearly all OECD member states during the 2000's, 
with the fastest rate measured directly before the crisis. The highest growth rate was recorded in the Baltic States, where it reached 30 per cent, followed by the Central and Eastern European countries, where indebtedness increased at a rate exceeding 20 per cent. After the crisis, increase in indebtedness slowed, and in a few countries the trend even turned (the Baltic States saw a drop by about 35 per cent in a year). In 2015, the highest indebtedness ratio was measured for Danish households (a value corresponding to 300 per cent of the disposable annual incomes), while Hungary showed the lowest ratio (approx. 51\%). Hungarian households' relatively lower indebtedness was, on the one hand, due to the fact that home lending picked up in Hungary right in the years preceding the crisis (and consequently, the funds used for redemption $a b$ ovo limited additional rise in the loan portfolio). The other reason included the high interest premiums in the roughly fifteen years to follow the 1990 change of regime in Hungary, especially on loans settled in the national tender (HUF), as this somewhat moderated HUF-based borrowing. The significant lending boom, unfolding from the mid2000's, was manifest in favorable rate FX loans, and as a result of volatile exchange rates, by $2007-2008$, it had caused grave economic and social problems, which in turn reduced bank lending, and moreover, a credit crunch had developed and could not be relieved until the mid-2010s.

An international and regional comparison of Hungarian household loans and of the current developments in lending reveals an apparent acceleration in the growth rate at the moment, despite the debt cap rules imposed to prevent large-scale household indebtedness (Zabai, 2017). In a macro-prudential perspective, it is in any case desirable that loan portfolio expansion should take place in an appropriate structure, sustainably, accompanied by an intense price competition, including a wider scope of customers and parallel with sustainable income growth.

An analysis of the time lines of Hungarian household borrowing reveals that after the relapse that followed the 2008 financial crisis, by now loan portfolios have again reached the previous levels (Figure 1) ${ }^{1}$. Household debt comprises for the most part home loans and personal loans. In the years after the outburst of the crisis, loan portfolios dropped due to a decline in households' borrowing capacity, to banks' more cautious allocation resulting from a drop in confidence, and to the government's regulatory and debtor rescue actions. Simultaneously with the financial consolidation of the Hungarian economy, due to the central bank's incentive policy and as a result of the family policy incentives (leverage incentive complementary to increasing wages), after 2015 the appetite for loans began to pick up again, as the family housing benefit and support to mortgage loans considerably boosted demand for housing loans (Sági \& Lentner, 2018).

As at January 1, 2015, the Hungarian government adopted a debt cap regulation setting mandatory payment-to-income and loan-to-value ratios for lending banks ${ }^{2}$. The purpose of the former is to prevent retail customers' excessive indebtedness and to secure their repayment ability by placing a cap on the portion of the monthly income used for debt redemption. On the other hand, the latter primarily protects banks by minimizing loss on default: the amount of loan allowed to be taken out is limited relative to the collateral value. Its purpose is to provide adequate security in the case of eventual impairment.

On October 1, 2018, the rules applicable to the payment to income ratio changed ${ }^{3}$. Change was

1 Note that as a result of the government's extensive family support regime, since 2015 non-refundable government subsidy has been allocated in an amount equal to the household sector's annual net credit position.

2 In the case of the payment-to-income ratio, the debtor's monthly repayment instalment may not exceed 50 per cent of his or her regular, legitimate income if it is less than HUF 400,000 and 60 per cent if it is equal to or more than that. More rigorous conditions were set for FX loans: the cap was set at 25 or 30 per cent on EUR loans and 10 or 15 per cent on other FX loans. For the loan-to-value ratio it was provided that in the case of mortgage loans, the amount granted may not exceed 80 per cent of the value of the property pledged as collateral, and in the case of motor vehicle loans, 75 per cent of the motor vehicle. Regulation was also tightened considerably for FX loans: the cap was set at 50 or 45 per cent on EUR loans and 35 or 30 per cent on loans denominated in other currencies except HUF.

3 When HUF mortgage loans with an interest period less than 5 years are taken out, the debtor's monthly repayment instalment may not exceed 25 per cent of his or her regular monthly net income, or 30 per cent if such income is higher. In the case of new HUF mortgage loans with an interest period longer than 5 but shorter than 10 years, this ratio may be 35 or 40 per cent of the regular monthly net income. Due to the lower interest rate risk, the 50 and 60 per cent PIT ratio was not changed for mortgage loans with an interest rate fixed for at least 10 years or until the end of their loan terms. Similarly lower limits should be applied to mortgage loans with shorter interest rate periods, taken in a currency other than forint. 


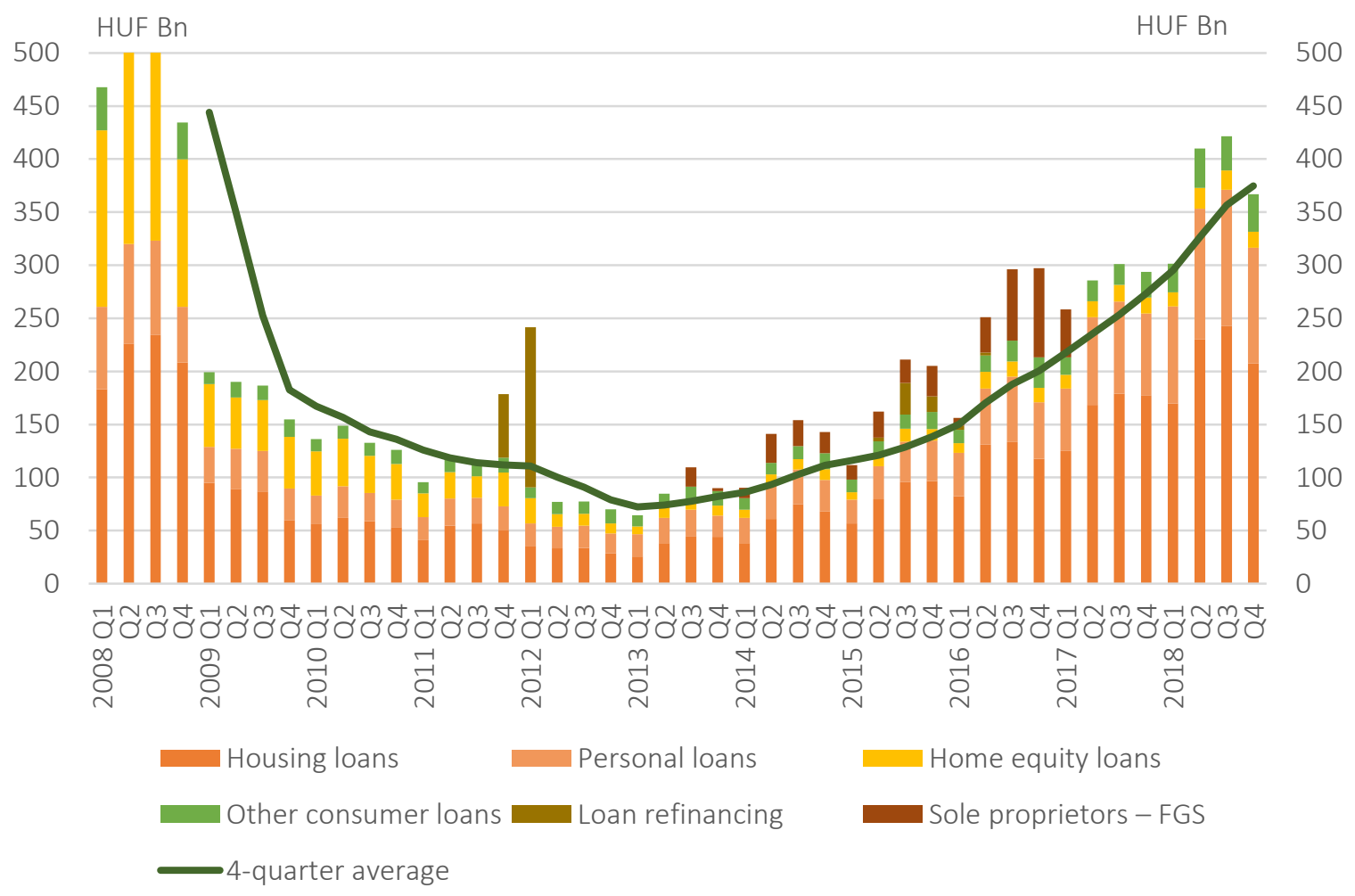

Figure 1. New household loans in the Hungarian credit institution sector ${ }^{4}$

justified by the altered interest conditions: as interests were rising, it became important to moderate the preponderance of variable rate loans and boost fixed-rate loans with longer interest periods in order to reduce households' risk exposure. For this reason, the legislator tightened the limits to payment-to-income ratio in the case of mortgage loans with shorter interest periods (National Bank of Hungary, 2014; 2018). Thus due to problematic loans outstanding, the legislator tightened the borrowing conditions and completely squeezed FX loans from the market.

Increase in the number of nonperforming credit debtors also led to similar actions (to prevent households' further indebtedness) in other European countries (Dancsik et al., 2015). Thus for example, the National Bank of Ireland set target values for financial institutions, and if in respect of the sustainable restructuring of mortgages, a bank fails to meet any of the target values, it is required to recognize higher impairment. In Spain, a 2.5 per cent cap was placed on loan rates for the households most in need in 2012 (which was then changed to 2 per cent in 2013), and requirements were specified for sustainable loan restructuring. It was also provided that if the restructuring plan elaborated by the lender bank proves to be unsustainable, in other words, if the PTI calculated on the basis of the aggregated monthly household income exceeded 60 per cent (and then from 2013, 50 per cent), banks were allowed to offer loan debtors partial debt discharge. Among CentralEuropean countries, Croatia, Poland and Serbia may be quoted as examples: in all these three countries, debt relief measures were adopted for loans settled in foreign exchange. It should be noted, however, that almost uniquely, the Hungarian regulation not only provides debt relief measures but also places caps on new allocations, and this solution is far more efficient in a macro-prudential perspective (Fáykiss et al., 2017).

\subsection{Financial literacy in the international literature}

The financial environment consumer experience in the current societies has really become considera-

4 In this period, the HUF/EUR rate varied between 270 and 325 and is currently (July 2019) 325. In comparison: before the sub-prime crisis, namely, in the mid-2000's, the HUF/EUR rate was around 230. 
bly higher-risk (more unpredictable) within a single generation. The accumulation of household loan portfolios, the lending boom, then the credit crisis and the debtor rescue packages have re-written the correlation between yield and risk in financial products. The process closely related to household lending was the erosion of savings. In the absence of savings, households are compelled to have recourse to loans again and again whenever they face pressing expenditures, and this condition may lead to a debt trap if new loans are taken out recklessly. The most important problem is the insufficient level of financial literacy, as this can result in offers that may seem to be attractive may trigger wanton borrowing (Dobák \& Sági, 2005; Sági, 2012).

If the propensity to save is low in a society, consumer loans are far more likely to be chosen for major expenses, and the risk of eventual insolvency is also higher for the simple reason that in a changed income situation, a debtor will not have reserves to survive more difficult times and can easily get into a situation when he or she is unable to repay his or her loan on time (Rick et al., 2008).

Initiating economic policy interventions to improve financial literacy is a reasonable response to the increase in risks due to the complexity of the financial environment (Bateman et al., 2011). In this context it is worth taking account of the policy mix tools suitable for having the most efficient impact on consumer decisions. Other contributing factors include the extent of premeditation or impulsiveness in household saving and borrowing decisions, the likelihood of making the wrong decisions and their predictability and restorability by the decision-maker (Croy et al., 2010; Courchane \& Zorn, 2008). The improvement of financial literacy with the help of government institutions, primarily central banks, and its practical implementation manifest at commercial banks falls, however, within banks' social responsibility. As a result of the crisis, more responsible and more conscious banking policies have been gaining increasing ground in both central and commercial banking, with focus on social matters and a higher level of responsibility for bank clients' management at the level of commercial banking (Lentner et al., 2015).

According to the methodology elaborated by the OECD International Network on Financial
Education (OECD-INFE, 2016), financial literacy is surveyed in about 30 countries (including 17 OECD member states) once in every three years to gain insight into the financial literacy of the population and their needs in terms of education and other forms of support. The method contains a questionnaire inquiry in order to assess the financial literacy and financial inclusion of the responding households.

In its disclosure of the 2015 international survey findings, OECD worded a financial policy recommendation for interlinking the regulatory and consumer protection frameworks with financial education in order to improve households' financial resilience to economic shocks. Linking financial regulation to the consumer protection frameworks may help households in preventing the debt trap caused by undertaking high debt and running into late payments (Guerrieri \& Lorenzoni, 2017). This can mitigate the probability of deterioration in households' financial position as a result of choosing financial products inappropriate for their current real-life scenario. Independent financial and investment consultancy services supported by the regulatory environment may help households in achieving their long-term goals even under the current rapidly developing financial conditions (OECD-INFE, 2018; Hansen, 2012).

The 2018 survey made in Hungary is linked to the initiative taken by OECD International Network on Financial Education, and as its methodology follows the uniform international frameworks, the findings can be compared to those obtained in more than 30 countries. The terms used in the survey follow the definition adopted by OECD/INFE for financial literacy considered as a combination of awareness, knowledge, skills, attitude and behavior required for a person to make reliable financial decisions and ultimately achieve financial welfare. This term refers to a person's proficiency in managing finances (Fernandes et al., 2014) as a form of the human capital (Remund, 2010). A survey of financial literacy may serve as a guideline in the elaboration and improvement of both financial education and the consumer protection regime (Kempson, 2009).

According to the literature, financial education can be expected to hand down up-to-date knowl- 
edge on financial investments and assets as well as banking and investment products; to shed light on fundamental financial correlations (such as the time value of money, the need to diversify investment portfolios, etc.); and to provide a glimpse into the procedure of planning, implementing and evaluating financial decisions (Hogarth, 2006; Haynes-Bordas et al., 2008).

The significance of the current findings is that they prove, through the example of Hungary, that financial awareness closely correlates with household saving and borrowing patterns (for its international background, see Mitchell and Lusardi (2015)). The findings of the analysis allow the spotting of threats resulting from the deterioration of financial literacy and the elaboration of a country-specific strategy to improve literacy (in the international literature see, e.g. Atkinson and Messy (2012)).

Financial literacy includes numerous forms of behavior that may promote financial welfare (Quach, 2016). One of them is saving (Lusardi \& Mitchell, 2017; Lusardi \& Tufano, 2015). Regular savings may contribute to smoothing fluctuations in revenues and expenditures and improve the predictability of incomes and expenses (Galperti, 2017). Propensity to plan may facilitate increase in private assets through reasonable investments (Ameriks et al., 2003). Lynch et al. (2010) defined planning the use of financial savings as a habit to set targets for household expenditures, outlining alternative methods of achieving them with consideration to the impacts of limiting factors and other conditions on the outcome. Financial literacy may be instrumental in planning long-term household assets, whether through the purchase and holding of stock-exchange traded investment securities or through retirement pre-savings (Van Rooij et al., 2011; Clark et al., 2006).

Nevertheless, financial literacy can only be significantly shaped over the long term, if at all. Given on 126 impact analyses, Kaiser and Menkhoff concluded that financial training courses improve the population's financial skills in general, but typically not in the case of lower-income social layers (Kaiser \& Menkhoff, 2017). On the other hand, borrowing habits are extremely difficult to influence, irrespectively of social layers.

\subsection{Findings of the survey of financial literacy in Hungary}

The survey is related to the initiative taken by OECD International Network on Financial Education, and as its methodology follows the uniform international frameworks. This paper analyzes the findings of the 2018 research. The survey analyzes the adult Hungarian population and in adjustment to the uniform international methodology, a sample of 1,000 persons was picked in the age group between 18 and 79, resident in Hungary (GFK \& MNB-Pénziránytű Alapítvány, 2018).

The results obtained after a minor adjustment (weights used: 0.5-2.2) can be considered as representative of county, community size, gender, age and qualifications. The headcount of the population constituting the target group of the research was 7,635,000 in 2018. Table 1 illustrates the distribution of the sample according to gender, age and qualifications.

Table 1. Composition of respondents

Source: Hungarian questionnaire survey.

\begin{tabular}{|c|c|c|c|c|}
\hline & $\begin{array}{c}\text { Unweighted } \\
\text { number } \\
\text { of elements }\end{array}$ & $\begin{array}{c}\text { Weighted } \\
\text { number } \\
\text { of } \\
\text { elements }\end{array}$ & As \% & $\begin{array}{c}\text { Thousand } \\
\text { persons }\end{array}$ \\
\hline TOTAL & 1,001 & 1,001 & 100 & 7,635 \\
\hline Women & 527 & 526 & 53 & 4,008 \\
\hline Men & 474 & 475 & 47 & 3,627 \\
\hline 18-29 years of age & 197 & 195 & 20 & 1,489 \\
\hline $30-39$ years of age & 149 & 148 & 15 & 1,127 \\
\hline 40-49 years of age & 225 & 222 & 22 & 1,694 \\
\hline $50-59$ years of age & 148 & 147 & 15 & 1,122 \\
\hline $60-69$ years of age & 181 & 181 & 18 & 1,382 \\
\hline $70-79$ years of age & 101 & 108 & 11 & 822 \\
\hline $\begin{array}{l}\text { With secondary } \\
\text { school } \\
\text { qualifications }\end{array}$ & 123 & 188 & 19 & 1,435 \\
\hline $\begin{array}{l}\text { Secondary school } \\
\text { qualifications with } \\
\text { a completed final } \\
\text { examination and } \\
\text { a professional } \\
\text { qualification }\end{array}$ & 148 & 120 & 12 & 915 \\
\hline $\begin{array}{l}\text { Secondary school } \\
\text { qualifications with } \\
\text { a completed final } \\
\text { examination }\end{array}$ & 260 & 208 & 21 & 1,589 \\
\hline $\begin{array}{l}\text { Secondary school } \\
\text { qualifications } \\
\text { without a final } \\
\text { examination }\end{array}$ & 290 & 234 & 23 & 1,787 \\
\hline $\begin{array}{l}\text { Primary school } \\
\text { or less }\end{array}$ & 180 & 250 & 25 & 1,909 \\
\hline
\end{tabular}


Financial literacy presupposes that households plan the spending and reasonable use and scheduling of their disposable income. Based on the responses recorded during the 2018 inquiry, Hungarian households give a highly unfavorable statistics in a European context: no more than 21.4 per cent make a budget. The ratio of households that pre-plan their revenues and expenditures is higher but, according to the authors, still not enough: they represent 45.8 per cent. It was found that irrespectively of other characteristic features (such as the location, qualifications, employment status), monthly budget planning has not become a habit in Hungarian households.

Based on the questionnaire survey made in Hungary, one-fifth $(20 \%)$ of the surveyed population got into a situation during the past twelve months that their incomes failed to cover their subsistence costs. As expected, the highest ratio (30\%) of households facing financial problems was measured among those in the lowest income bracket, but one of ten households (10\%) has experienced such a problem even among those with higher than average incomes. People with vocational or other secondary school and higher qualifications gave 53 per cent of the sample, and 87 per cent of them had a stable livelihood, while nearly one-third $(30 \%)$ of the households with lower qualifications have already found themselves in distressing circumstances. More than one-fourth (28\%) of the respondents can only close the gaps and make ends meet by regularly relying on bank loans (overdraft, bank card overspending and personal loans).

The active propensity to save, measured retroactive to 12 months and assessed in the survey, displays the respondents' saving habits. (In this context increase in the positive current account balance cannot be considered as an active feature, as by default it is not accompanied by a time deposit option.) In an international comparison, the ratio of actively saving households is extremely low in Hungary: no more than 18 per cent of the respondent households deposited money on their savings accounts, 2 per cent purchased bonds or invested in investment funds, and 1 per cent held shares.
Half (49\%) of the surveyed households had enough funds to cover unexpected expenses amounting to a monthly income, while 42 per cent would surely be incapable of doing so. Naturally, a more favorable view was obtained for households with incomes above HUF 300,000 per month ${ }^{5}$, however, one-third (32\%) of the respondents would still be unable to cover such an expense. In addition to an unexpected expenditure, crisis can be created by the absence of revenues. At least 35 per cent of the respondents could certainly be unable to overcome the loss of a monthly income without any trouble. The ratio of households equipped to finance a period of one to three months is similar in the various income brackets (fluctuating between 25 and 28\%), however, the fact that half (47\%) of the consumers capable of surviving such a period for more than three months live in households with above-average incomes suggests asset concentration.

The ratio of households that compare financial products on the basis of their conditions or that seek the advice of financial consultants when making decisions is low in Hungary. The question concerning the applied sources of information indicates households' utilization of the benefits provided by independent consultants before picking a particular financial product (see also Diehl et al., 2003; Calcagno \& Monticone, 2015). This ratio was merely 9 per cent of the respondents. Note that according to the literature the existence of independent financial consultants alone is an insufficient precondition to the improvement in financial literacy (McCormick, 2009).

Based on the data obtained from the survey, the responses given to the questions concerning planning (budgeting), bridging gaps created by unexpected expenses and savings habits are analyzed with the help of their distribution and cross-tables. The respondents' characteristic features were analyzed according to region, community type, age group, qualification and employment status. The underlying assumption was that correlation between the variables is confirmed if the Pearson $\mathrm{Chi}^{2}$ test is less than 5 per cent (the significance level marked in social sciences). It was recorded that in the range between 0 and 1 of the Cramer

5 In other words, in the income bracket of approximately EUR 925 monthly net (20 per cent higher than the wage that is currently average in Hungary). In comparison, it is noted that the net wages paid in Hungary fail to amount to even 60 per cent of the average wages paid in the European Union (Eurostat, 2018). 


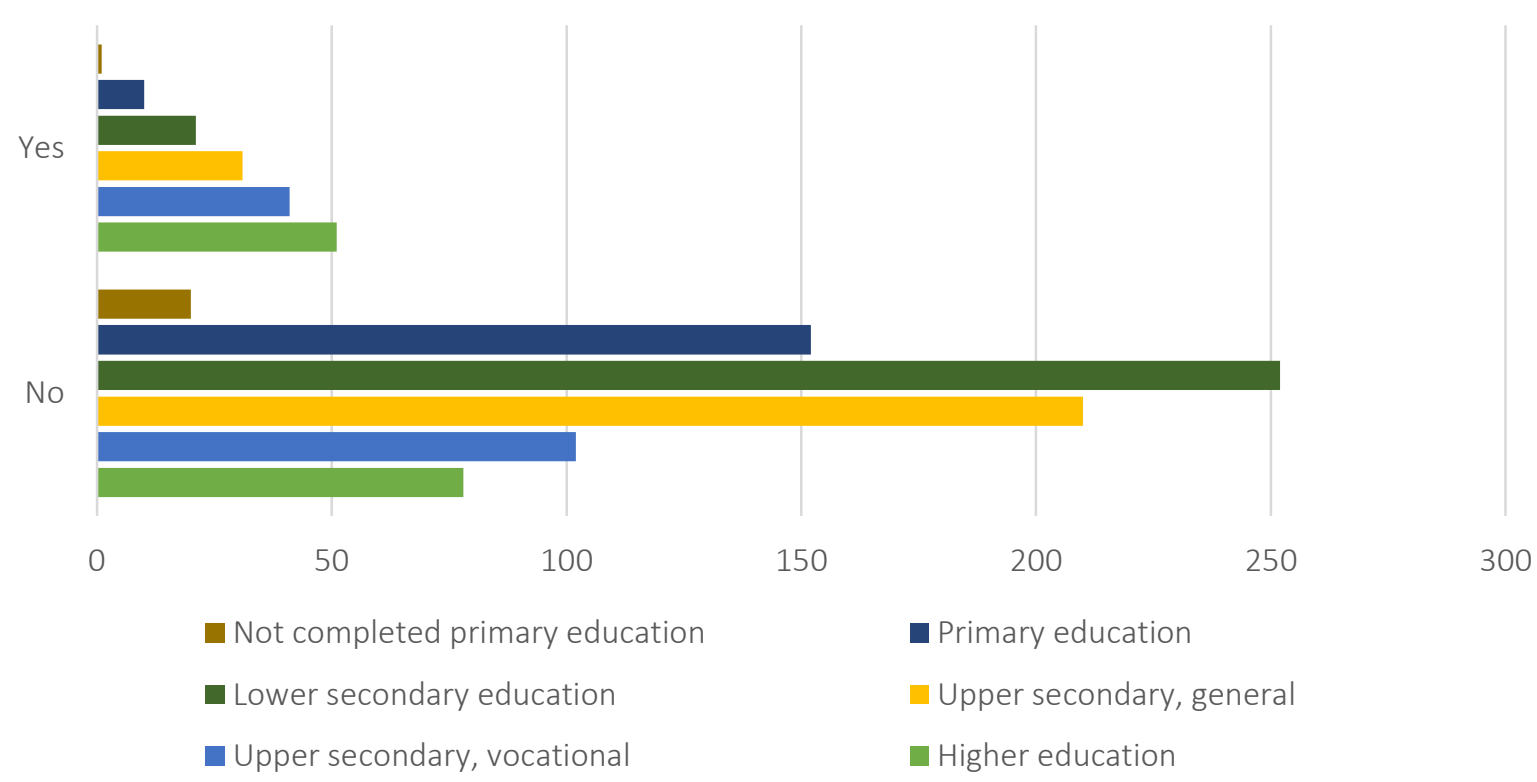

Figure 2. Having a savings account and the respondent's qualifications; cross-table and analysis from an SPSS output

$\mathrm{V}$ indicator measuring the closeness of the correlation, Hungary scores slightly below (close to 0.5 ) and slightly better (above 0.5 ) than the mean value.

The findings of the statistical cross-table analysis suggest that higher qualification is the only factor that suggests a slightly positive margin in saving habits (Figure 2 and Table 2). The literature disputes any positive correlation between qualification and the propensity to save; and probably there is no educational program that is uniformly applicable to all (Hastings et al., 2012). In the case of the other variables the mases behave uniformly.

Table 2. Savings account and the respondent's qualifications; cross-table and analysis

Source: Own from SPSS output.

\begin{tabular}{l|c:c:c}
\hline \multicolumn{3}{c}{ Chi-squared tests } \\
\hline & Value & df & $\begin{array}{c}\text { Asymp. sig. } \\
\text { (2-sided) }\end{array}$ \\
\hline Pearson Chi-square & $104,648^{a}$ & 5 & 0.000 \\
\hline Likelihood ratio & 99.490 & 5 & 0.000 \\
\hline Linear-by-linear & 95.174 & 1 & 0.000 \\
association & 984 & & \\
\hline Number of valid cases & & & \\
\hline
\end{tabular}

Note: ${ }^{a} 1$ cell $(8.3 \%)$ has an expected count less than 5 . The minimum expected count is 4.29 . The Cramer $V$ value was 0.426 .

The results obtained call the attention to the threat that - irrespectively of their location, age, employment status, and frequently even qualifications -
Hungarian households' habits and situation are consistent: they do not plan their income position, fail to estimate their extraordinary expenditures, in other words, their financial awareness is low. On the other hand, the reason for the adverse impression of households is that they nearly consistently do not have any bank savings and financial investments they could use as reserves during financial shocks. Many of them have already been indebted.

Twenty-two per cent of the households with loans would only be able to pay their instalments for no longer than a single month if the head of the household lost his or her job, and only a mere 9 per cent could continue to pay redemption for at least six months. Overall, 15 per cent of the loan debtors are vulnerable and additional 12 per cent are on the verge of becoming vulnerable. In other words, one of three debtors may run into problems. Banks run a key risk if debtors use expensive personal loans for raising the minimum fund required as their own contribution to home loans. Recently, the Hungarian central bank has been encouraging the allocation of fixed-interest rate loans for longer interest periods (up to 15 years), as the longer the interest period, the more predictable the repayment amount for the customer. However, security also has a price: higher monthly repayment instalments are charged for fixed-interest than for variable interest loans. 


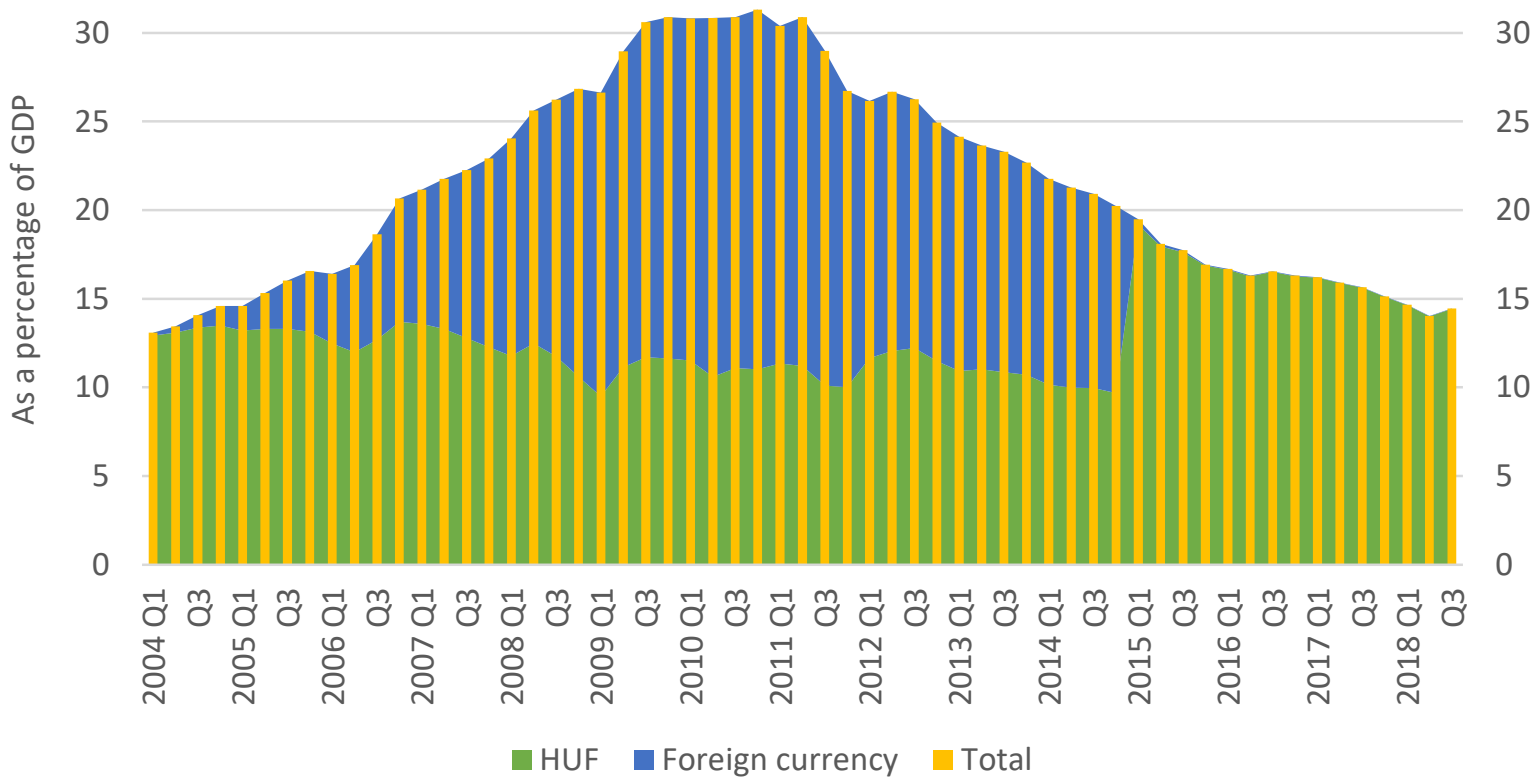

Figure 3. Distribution of the household sector's mortgage loans borrowed from credit institutions, in a breakdown of currency

The still unfavorable level of financial literacy measured in Hungarian households is so much the more remarkable in view of the fact that in an environment characterized by inefficient economic and employment policies in the decade after 2000 , the population raised funds from the credit market to cover their increasing demand ${ }^{6}$. For the most part, demand for consumer and housing loans is manifest in a rise in the portfolio of FX-settled loans. After the economic, and more specifically, household FXloan, consolidation ${ }^{7}$, similarly to other Central European countries, central steps were taken to relieve the repayment burdens of households indebted in foreign exchange and to eliminate the exchange rate risk.

Figure 3 clearly illustrates the previous period, which started with most Hungarian households indebted in foreign exchange as a result of the benefit expected at the time these loans were granted, and which was characterized by a rapid increase in debt portfolios due to the crisis. Parallel with the unfavorable developments in exchange rates, deterioration in debtors' in come situation generated risks on a social scale. In response, after 2011 the regulatory authority took action to gradually mitigate systemic risk, and after 2013 foreign exchange loans were converted into forint loans (representing lower interest rate risks and eliminating exposure to exchange rates) to the debit of the National Bank of Hungary's FX reserves (Matolcsy \& Palotay, 2018).

Thus in 2015, foreign exchange-denominated household loans practically ceased to exist in Hungary, and the situation of the population seemed to return to normal (Lentner, 2015), however, the conditions of the conversion of FX-loans to HUF-loans have been generating repeated litigations at times transferred to international courts, the main element in such actions being a reference made to the absence of adequate financial literacy on the part of the population and to the "misleading" conduct on the part of banks, which resulted (in the opinion of the litigants) in damages suffered due to

6 In the decade after 2000, the unemployment rate was between 6 and 7 per cent in Hungary, and peaked at 11 per cent during the crisis. However, by now it has dropped to about 3 or 4 per cent. Over the same period the inflation rate moderated from 10 to around 1-3 per cent.

7 In 2013, Hungary was released from the European Union's Excessive Deficit Procedure. 
the conversion, which has remained unsettled to this date (Bodzási, 2019). It is a fact that the disputed matters related to FX-loan contracts have enhanced the disadvantages the population suffered - partly due to the absence of financial knowledge (Banai \& Kolozsi, 2018), however, as a result of the conversion of FXloans to HUF-loans and with the interruption of FX-lending on could have expected risk resilience to improve in the household sector. Nevertheless, the excessively "lax" attitude of the population is unmatched among the other countries of the region, especially in view of the fact that subsequently the regulatory authority adopted debt cap rules that are forward-looking in a macro-prudential perspective (Lentner, 2016). The application of the latter is justified by an increase in the risk of macro-economic overheating (as due to the favorable macro-economic course, increase in the income levels, the extensive family support system, households have a massive demand for loans), with special consideration to the fact that household stability and financial literacy have not improved significantly in recent years despite the preventive actions taken by government regulation.

\section{CONCLUSION}

As loans and borrowings improved from the favorable economic course in the late 2010s, a sharp increase was recorded for both home and consumer loans. Due to the favorable economic climate, fiscal incentives applied in housing policy and the changes in the living conditions (rising wages, dropping unemployment, etc.), Hungarian households have less hesitation to borrow. However, the stable ability to repay loans is often a simple illusion: the analysis of the financial literacy surveys concluded that households are financially vulnerable, most of them do not compile budgets in advance and do not have any reserves for any period of financial shocks.

The example of Hungary also sheds light on the fact that despite the adoption of debt limits, the regulatory authority compels credit institutions to prudential lending, relatively high credit margins and interest income in the sector contribute to an increase in credit supply, as well as the high demand population who "absorbs" loans in almost unlimited amount.

The findings confirm the view in the literature that financial literacy is closely correlated with the household saving and borrowing patterns, and if insufficient, threatens long-term household well-being. Based on the example of Hungary it was found that financial vulnerability characterizes households in general; this is not closely related to geographical location, age, employment status or qualifications, and moreover, disposition to excessive indebtedness is not only displayed in a poor macro-economic political environment, but also during boom, while financial literacy is unlikely to improve. The authors believe that maintaining strict debt limits and prudential rules may help keep the lid on household indebtedness, otherwise they will grow excessively until it becomes non-repayable. As living conditions improve, Hungarian households incur additional debt without assessing the risk of their impairment.

\section{ACKNOWLEDGMENT}

In a part of Prof. Lentner, this study was supported by the PADS (Hungarian National Bank Foundation) Leader Expert Program. 


\section{REFERENCES}

1. Akinci, O., \& OlmsteadRumsey, J. (2015). How effective are macroprudential policies? An empirical investigation (International Finance Discussion Papers No. 1136). Board of Governors of the Federal Reserve System. https://doi.org/10.17016/ IFDP.2015.1136

2. Ameriks, J., Caplin, A., \& Leahy, J. (2003). Wealth accumulation and propensity to plan. The Quarterly Journal of Economics, 118(3), 1007-1047. https://doi. org/10.1162/00335530360698487

3. Atkinson, A., \& Messy, F. (2012). Measuring Financial Literacy: Results of the OECD / International Network on Financial Education (INFE) Pilot Study (OECD Working Papers on Finance, Insurance and Private Pensions No. 15) (pp. 1-72). OECD Publishing, Paris. https://doi. org/10.1787/5k9csfs90fr4-en

4. Banai, Á., \& Kolozsi, P. (2018). Fenntartható hitelpiac, fenntartható fejlődés. (Sustainable Credit Market, Sustainable Development). Köz-gazdaság, 13(2), 135-143. https://doi. org/10.14267/RETP2018.02.07

5. Bateman, Z., Eckert, C., Geweke, J., Louviere, J., Thorp, S., \& Satchell, S. (2011). Financial Competence and Expectations Formation: Evidence from Australia. Economic Record, 88(280), 39-63. https://doi.org/10.1111/j.14754932.2011.00766.x

6. Boar, C., Gambacorta, L., Lombardo, G., \& da Silva, L. P (2017). What are the effects of macroprudential policies on macroeconomic performance? BIS Quarterly Review, 3, 71-88. Retrieved from https://www.bis. org/publ/qtrpdf/r_qt1709g.pdf

7. Bodzási, B. (2019). A deviza alapú fogyasztói kölcsönökhöz kapcsolódó problémák kezelésére irányuló jogi lépések Magyarországon. (Legal Steps to Address Issues Related to FX-Based Consumer Loans in Hungary). In Bodzási \& Balázs (Eds.), Devizahitelezés
Magyarországon: a devizahitelezés jogi és közgazdasági elemzése (FX Loans in Hungary - Legal and Economic Analysis) (pp. 57-94). Budapesti Corvinus University/

8. Calcagno, R., \& Monticone, C. (2015). Financial literacy and the demand for financial advice. Journal of Banking \& Finance, 50, 363-380. https://doi.org/10.1016/j. jbankfin.2014.03.013

9. Carreras, O., Davis, E., \& Piggott, R. (2016). Macroprudential tools, transmission and modelling (Discussion Paper No. 470). National Institute of Economic and Social Research. https://doi. org/10.2139/ssrn.2967270

10. Cerutti, E., Claessens, S., \& Laeven, L. (2017). The use and effectiveness of macroprudential policies: new evidence. Journal of Financial Stability, 28(C), 203224. https://doi.org/10.1016/j. jfs.2015.10.004

11. Clark, R., d'Ambrosio, M., McDermed, A., \& Sawant, K. (2006). Retirement Plans and Saving Decisions: The Role of Information and Education. Journal of Pension Economics and Finance, 5(1), 45-67.

12. Courchane, M., \& Zorn, P. (2008). Consumer Credit Literacy: What Price Perception. Journal of Economics and Business, 60, 125138.

13. Croy, G., Gerrans, P., \& Speelman, C. (2010). The Role and Relevance of Domain Knowledge, Perceptions of Planning Importance, and Risk Tolerance in Predicting Savings Intentions. Journal of Economic Psychology, 31(6), 860-871

14. Dancsik, B., Fábián, G., Fellner Z., Horváth, G., Lang, P., Nagy, G., Oláh, Zs., \& Winkler, S. (2015). Comprehensive analysis of the nonperforming household mortgage portfolio using micro-level data (MNB Occasional Papers Special Issue). Retrieved from https:// www.mnb.hu/letoltes/mnb-occasional-papers-special-issue.pdf
15. Dancsik, B., Kolozsi, P. P., \& Winkler, S. (2017). Monetarcy Policy Considerations for the Conversion of Foreign Currency Loans Growing Stability and Central Bank Leeway. In K. Lehmann, D. Palotai, \& B. Virag (Eds.), The Hungarian Way: Targetted Central Bank Policy (pp. 420-463). National Bank of Hungary.

16. Diehl, K., Kornish, L. K., \& Lynch, J. G. (2003). Smart agents: When lower search costs for quality information increase price sensitivity. Journal of Consumer Research, 30(1), 56-71. https://doi. org/10.2139/ssrn.340040

17. Dobák, P., \& Sági, J. (2005). Fogyasztási hitelek: növekvő eladósodottság? (Retail loans: increasing indebtedness?). Hitelintézeti Szemle/Financial and Economic Review, 4(1), 1-27. Retrieved from http://www. bankszovetseg.hu/Content/ Hitelintezeti/51Dobak_Sagi.pdf

18. Eurostat (2018). Wages and labour costs. Retrieved from https:// ec.europa.eu/eurostat/statisticsexplained/index.php?title=Wages_ and_labour_costs

19. Fáykiss, P., Nagy, M., \& Szombati, A. (2017). Regionally-differentiated debt cap rules: a Hungarian perspective. (BIS Papers No. 94) (pp. 153-178). Retrieved from https://www.bis.org/publ/bppdf/ bispap94l.pdf

20. Fáykiss, P., Palicz, A., Szakács, J., \& Zsigó, M. (2018). Experiences of Debt Cap Regulations in Hungarian Retail Lending. Financial and Economic Review, 17(1), 34-61. Retrieved from http://english.hitelintezetiszemle. hu/letoltes/fer-17-1-st2-faykisspalicz-szakacs-zsigo.pdf

21. Fernandes, D., Lynch, J. G., \& Netemeyer, R. (2014). Financial Literacy, Financial Education, and Downstream Financial Behaviors. Management Science, 60(8), 18611883. https://doi.org/10.1287/ mnsc. 2013.1849

22. Galperti, S. A. (2017). Theory of Personal Budgeting. SSRN 
Electronic Journal, 1-58. https://doi. org/10.2139/ssrn.2964067

23. GFK and MNB-Pénziránytü Alapítvány. (2018). Lakosság pénzügyi kultúrája. Kutatási jelentés a Pénziránytü Alapítvány részére. Growth from Knowlegde (Unpublished manuscript), pp. 1-67.

24. Guerrieri, V., \& Lorenzoni, G. (2017). Credit Crises, Precautionary Savings, and the Liquidity Trap. The Quarterly Journal of Economics, 132(3), 1427-1467. https://doi. org/10.1093/qje/qjx005

25. Hansen, T. (2012). Understanding Trust in Financial Services: The Influence of Financial Healthiness, Knowledge, and Satisfaction. Journal of Service Research, 15, 280-295. https://doi. org/10.1177/1094670512439105

26. Hastings, J. S., Madrian, B. C. \& Skimmyhorn, W. L. (2012). Financial literacy, financial education, and economic outcomes (NBER Working Paper No.18412). Cambridge, MA: National Bureau of Economic Research. Retrieved from http://www.nber.org/papers/ w18412

27. Haynes-Bordas, R., Kiss, D. E., \& Yilmazer, T. (2008). Effectiveness of Financial Education on Financial Management Behavior and Account Usage: Evidence from a 'Second Chance' Program. Journal of Family and Economic Issues, 29(3), 362-390.

28. Hogarth, J. (2006). Financial education and economic development (OECD Working Paper). Retrieved from http://www. oecd.org/dataoecd/20/50/37742200. pdf

29. Hungarian National Bank. (2014, 2018). Az MNB az adósságfék szabályok módosításával is ösztönzi a fix kamatozású lakáshitelek térnyerését. (Upper limit on the payment-to-income ratio protects households as a debt cap.) Press release.

30. Hungarian National Bank. (2017, 2018). Macro prudential report. Retrieved from https://www.mnb. hu/letoltes/mnb-macroprudentialreport

31. Hungarian National Bank. (2019). Trends in lending, March 2019.
Retrieved from https://www.mnb. hu/en/publications/reports/trendsin-lending/trends-in-lendingmarch-2019

32. Iyengar, S., \& Kamenica, E. (2010). Choice proliferation, simplicity seeking, and asset allocation. Journal of Public Economics, 94(7-8), 530-539. Retrieved from https:// faculty.chicagobooth.edu/emir. kamenica/documents/simplicitySeeking.pdf

33. Kaiser, T., \& Menkhoff, L. (2017). Does Financial Education Impact Financial Literacy and Financial Behavior, and If So, When? (Policy Research Working Papers). https:// doi.org/10.1596/1813-9450-8161

34. Kempson, E. (2009). Framework for the Development of Financial Literacy Baseline Surveys: A First International Comparative Analysis (OECD Working Papers on Finance Insurance and Private Pensions No. 1). OECD Publishing. https://doi. org/10.1787/5kmddpz7m9zq-en

35. Kovács, L. (2013). A devizahitelek háttere (Background of FX Loans). Hitelintézeti Szemle/ Financial and Economic Review, 12(3), 183-193. Retrieved from http://epa.oszk. hu/02700/02722/00066/pdf/ EPA02722_hitelintezeti_szemle_2013_3_183-193.pdf

36. Lentner, Cs. (2015). The Structural Outline of the Development and Consolidation of Retail Foreign Currency Lending. Public Finance Quarterly, 60(3), 297-311. https:// asz.hu/storage/files/files/Angol_ portal/public_finance_quarterly/ Archive/2015/a_lentnercs_2015_3. pdf

37. Lentner, Cs. (2016). A gazdasági világválság hatása a globális, uniós és hazai szabályozási környezetre (Impact of the Global Economic Crisis on the Global, EU and Domestic Regulatory Environment). In Á. Auer, \& T. Papp (Eds.), Impact of the Global Economic Crisis on Certain Legal Institutions in Hungary and the European Union: Interdisciplinary and Comparative Analysis (pp. 4584). Budapest: National University of Public Service.

38. Lentner, Cs., Szegedi, K., \& Tatay, T. (2015). Corporate Social
Responsibility in the Banking Sector. Public Finance Quarterly, 60(1), 95-103. Retrieved from https://www.asz.hu/storage/files/ files/public-finance-quarterlyarticles/2015/a_lentner_szegedi_ tatay_2015_1.pdf

39. Lusardi, A., \& Mitchell, O. S. (2017). How ordinary consumers make complex economic decisions: financial literacy and retirement readiness. Quarterly Journal of Finance (QJF), 7(03), 1-31. https://doi.org/10.3386/ w15350

40. Lusardi, A., \& Tufano, P. (2015). Debt literacy, financial experiences, and overindebtedness. Journal of Pension Economics and Finance, 14(04), 332-368. https://doi. org/10.1017/s1474747215000232

41. Lynch J. G., Netemeyer, R., Spiller, S. A., \& Zammit, A. (2010). A generalizable scale of propensity to plan: The long and the short of planning for time and money. Journal of Consumer Research, 37(1), 108-128. https://doi. org/10.1086/649907

42. Matolcsy, G., \& Palotai, D. (2018). The Hungarian Model: Hungarian Crisis Management in View of the Mediterranean Way. Financial and Economic Review, 17(2), 5-42. Retrieved from https:// en-hitelintezetiszemle.mnb.hu/ letoltes/fer-17-2.pdf

43. McCormick, M. H. (2009). The effectiveness of youth financial education: A review of the literature. Journal of Financial Counselling and Planning, 20(1), 70-83. Retrieved from https://files. eric.ed.gov/fulltext/EJ859566.pdf

44. Mitchell, O. S., \& Lusardi, A. (2015). Financial Literacy and Economic Outcomes: Evidence and Policy Implications. SSRN Electronic Journal. https://doi. org/10.2139/ssrn.2568732

45. OECD. (2017). Statistical Insights: What does household debt say about financial resilience? Retrieved from http://www.oecd. org/sdd/fin-stats/statisticalinsightswhatdoeshouseholddebtsayaboutfinancialresilience.htm 
46. OECD/INFE. (2016).

International Survey of Adult Financial Literacy Competencies. OECD, Paris. Retrieved from https://www.oecd.org/daf/fin/ financial-education/OECD-INFEInternational-Survey-of-AdultFinancial-Literacy-Competencies. pdf

47. OECD/INFE. (2018). Toolkit for Measuring Financial Literacy and Financial Inclusion. OECD, Paris. Retrieved from https:// www.oecd.org/finance/financialeducation/2018-INFE-FinLitMeasurement-Toolkit.pdf

48. Quach, H. (2016). Does access to finance improve household welfare? Investment Management and Financial Innovations, 13(2), 76-86. https://doi.org/10.21511/ imfi.13(2).2016.08

49. Remund, D. L. (2010). Financial literacy explicated: The case for a clearer definition in an increasingly complex economy. Journal of Consumer Affairs, 44(2), 276-295. https://doi.org/10.1111/ j.1745-6606.2010.01169.x

50. Rick, S. L., Cryder, C. E., \& Loewenstein, G. (2008) Tightwads and Spendthrifts. Journal of Consumer Research 34(6), 767-782. http://dx.doi. org/10.1086/523285

51. Sági, J. (2012). Debt trap monetary indicators of Hungary's indebtedness (MPRA Paper No. 40343). Retrieved from https://mpra.ub.uni-muenchen. de/40343/1/10-Debt_trap-monetary_indicators_of_Hungarys_indebtedness.pdf

52. Sági, J., \& Lentner, Cs. (2018). Certain Aspects of Family Policy Incentives for Childbearing - A Hungarian Study with an International
Outlook. Sustainability, 10(11), 3976. https://doi.org/10.3390/ su10113976

53. Seregdi, L., Szakács, J., \& Tőrös, Á. (2015). Micro- and macro prudential regulatory instruments compared across the European Union. Financial and Economic Review, 14(4), 57-86.

54. Van Rooij, M., Lusardi, A., \& Alessie, R. (2011). Financial literacy and stock market participation. Journal of Financial Economics, 101(2), 449-472.

Retrieved from https://econpapers. repec.org/article/eeejfinec/v_3a 101_3ay_3a2011_3ai_3a2_3ap_ 3a449-472.htm

55. Zabai, A. (2017). Household debt: recent developments and challenges. BIS Quarterly Review, 2017(4), 39-54. Retrieved from https://www.bis.org/publ/qtrpdf/r_ qt1712f.htm 